Sains Malaysiana 49(8)(2020): 1959-1967

http://dx.doi.org/10.17576/jsm-2020-4908-18

\title{
Analisis Tindak Balas Berantai Polimerase (PCR) Simpleks dan Multipleks ke atas Produk Surimi Terawat Terma bagi Pengesanan DNA Lembu dan Babi
}

(Simplex and Multiplex Polymerase Chain Reaction (PCR) Analysis of Heat Treated Surimi Product for Bovine and Porcine DNA Detection)

\author{
SAfiYyah Shahimi, Nur Syafiqa Akmal Ahmad GHaZali, Aishah Elias, Nurul AqILAH Mohd Zaini \& \\ SAHILAH ABD MUTALIB*
}

\begin{abstract}
ABSTRAK
Kajian ini dilakukan bagi mengesan DNA babi dan lembu daripada gelatin yang ditambah ke dalam surimi dengan menggunakan teknik tindak balas berantai polimerase (PCR) khusus-spesies simpleks dan multipleks. Bebola ikan berasaskan surimi telah dihasilkan dengan penambahan 5\% (w/w) gelatin lembu dan 5\% (w/w) gelatin babi serta dimasak menggunakan kaedah rebusan, pemanggangan, penggorengan dan autoklaf. Sebanyak tiga primer digunakan dalam analisis PCR iaitu sitokrom oksidase II (COII) untuk penentuan DNA lembu; dan dua primer untuk menentukan DNA babi, DNA mitokondria tRNA-ATP8 dan Elemen Nuklear Berselang Pendek (SINE). Analisis PCR simpleks menggunakan tiga primer khusus-spesies berjaya mengesan DNA lembu dan babi dalam kesemua sampel dengan penghasilan amplikon $165 \mathrm{bp}$ (COII), $212 \mathrm{bp}$ (RNA-ATP8) dan $161 \mathrm{bp}$ (SINE). Pengoptimuman PCR multipleks dengan menggunakan primer $t R N A-A T P 8$ dan SINE telah dilakukan dengan menggunakan program kitar; penyahaslian awal pada $95^{\circ} \mathrm{C}$ selama dua min, diikuti 30 kitaran penyahaslian pada $94^{\circ} \mathrm{C}$ selama 1 min, penyepuhan pada $55^{\circ} \mathrm{C}$ selama 1 min, pemanjangan pada $72{ }^{\circ} \mathrm{C}$ selama dua min dan pemanjangan akhir pada $72{ }^{\circ} \mathrm{C}$ selama sepuluh min telah berjaya mengamplifikasi dua gen sasaran bagi pengesanan DNA babi. Faktor seperti suhu $\left(121^{\circ} \mathrm{C}\right)$ dan tekanan (15 psi) terhadap rawatan terma didapati memberikan kesan kepada kualiti DNA di dalam sampel yang diautoklaf dan ini ditunjukkan dengan penghasilan amplikon yang pudar pada gel agarose. Oleh itu, kajian analisis PCR multipleks menggunakan primer babi khusus-spesies adalah kaedah mudah dan cepat untuk menentukan kehadiran DNA babi yang terkandung di dalam produk makanan terproses seperti surimi.
\end{abstract}

Kata kunci: DNA babi; gelatin babi; khusus-spesies; PCR multipleks; surimi

\section{ABSTRACT}

This research was carried out to detect the presence of pig and bovine DNA from gelatine added into surimi using species-specific simplex and multiplex polymerase chain reaction (PCR). Surimi-based fish balls were made with the addition of $5 \%(w / w)$ bovine gelatin and $5 \%(w / w)$ porcine gelatin and cooked using boiling, roasting, pan frying, and autoclaving methods. Three species-specific primers used in PCR analysis were cytochrome oxidase II (COII) for determination of bovine DNA; and two primers for determination of porcine DNA, mitochondrial DNA TRNA-ATP8 and Short Interspersed Nuclear Elements (SINE). Simplex PCR analysis using three species specific primers has been successfully detected bovine and porcine DNA in all samples by producing $165 \mathrm{bp}$ (COII), $212 \mathrm{bp}$ (tRNA-ATP8) and $161 \mathrm{bp}$ (SINE) amplicons, respectively. Optimization of multiplex PCR using tRNA-ATP8 and SINE primers was done with step cycle of initial denaturation at $95{ }^{\circ} \mathrm{C}$ for two min, followed by 30 cycles of denaturation at $94{ }^{\circ} \mathrm{C}$ for one min, annealing at $55^{\circ} \mathrm{C}$ for one min, polymerization at $72{ }^{\circ} \mathrm{C}$ for two min and a final extension at $72{ }^{\circ} \mathrm{C}$ for ten min was found to successfully amplify two target genes for detection of pig DNA. Several factors such as temperature $\left(121^{\circ} \mathrm{C}\right)$ and pressure $(15 \mathrm{psi})$ during the heat treatment were found to affect the quality of DNA in the autoclaved samples, which shown by the faded amplification products in agarose gel. Thus, multiplex PCR analysis using porcine species-specific primer are reliable and useful in order to determine the presence of porcine DNA in processed food products such as surimi.

Keywords: Multiplex PCR; porcine DNA; porcine gelatin; species-specific; surimi

\section{PENGENALAN}

Produk surimi merupakan antara penyumbang terbesar hasil pendapatan negara bagi industri makanan. Surimi atau bebola ikan amat digemari dan merupakan makanan terproses yang mengandungi kandungan protein ikan. Di Malaysia, surimi digunakan sebagai rencah dalam 
sayuran, kuah kari, tumisan dan rencah dalam gorengan mi. Bahan-bahan yang terdapat dalam surimi adalah daging ikan yang diekstrak dan bahan tambah makanan lain seperti pelindung krio iaitu sukrosa, sorbitol dan natrium pirofosfat serta sodium monoglutamat (Babji \& Gna 1994). Surimi merupakan protein otot miofibril ikan pada kepekatan tinggi yang telah dilarutkan oleh garam dan air pada suhu tertentu. Jenis bahan aditif yang digunakan akan menentukan pembentukan matriks gel surimi melalui interaksi yang hadir (Altun \& Yildiz 2018).

Bahan lain yang mungkin boleh dimasukkan ke dalam produk surimi ialah plasma darah atau gelatin yang dicampur di dalam produk surimi bagi memberikan tekstur yang baik dan kekenyalan yang diingini. Gelatin merupakan salah satu bahan aditif yang telah digunakan secara meluas bagi memperbaiki kestabilan dan kesejajaran sesuatu produk makanan terproses (Mahmoodani et al. 2014). Walaupun penambahan gelatin sebagai bahan aditif ke dalam formulasi surimi menghasilkan kekuatan gel yang rendah, penambahan bahan tambah lain seperti transglutaminase boleh menghasilkan surimi yang elastik dan diterima oleh pengguna (Guo et al. 2019). Oleh itu, penambahan gelatin boleh memberi tekstur yang lembut, mengurangkan kandungan kelembapan surimi yang merupakan faktor penting di dalam pembuatan surimi (Altun \& Yildiz 2018; Kaewudom et al. 2013) dan menaikkan jumlah komposisi protein daripada segi nutrisi. Gelatin berasal daripada sumber kolagen (Repin et al. 2019) dan dikenali sebagai protein terproses (Nikzad et al. 2017) kebiasaannya mengandungi jumlah sisa DNA yang amat sedikit. Penambahan rawatan terma semasa pemprosesan akhir dalam penyediaan produk berasaskan gelatin boleh menyumbang kepada kerosakan DNA yang lebih teruk justeru menyukarkan proses pengenalpastian sumber gelatin yang digunakan. Menurut Pascoal et al. (2005), walaupun DNA mempunyai kestabilan terma yang sangat tinggi, namun kombinasi pemanasan dan tekanan tinggi pada satu masa boleh menyebabkan kemusnahan DNA dan memberi kesan kepada kualiti DNA.

Kaedah PCR boleh digunakan bagi mengesan terbitan DNA secara khusus dengan kepekaan yang tinggi menggunakan set primer yang bersifat khususspesies (Yoshida et al. 2009). Penggunaan primer yang bersifat khusus-spesies adalah lebih mudah bagi mengesan terbitan DNA daripada spesies yang tertentu. Penggunaan primer ini berjaya mengenal pasti spesies sasaran secara khusus dalam format PCR simpleks mahu pun multipleks (Ghovvati et al. 2009). Menurut Shabani et al. (2015), teknik PCR khusus-spesies telah menunjukkan tahap kesensitifan yang tinggi dengan pengesanan $0.1 \%$ gelatin lembu di dalam gelatin babi. Dalam kajian ini, asai PCR khusus-spesies secara simpleks dan multipleks digunakan bagi mengesan kehadiran DNA lembu dan babi di dalam produk makanan surimi yang telah diberikan rawatan terma. Sebanyak 3 primer digunakan dalam analisis PCR iaitu sitokrom oksidaseII (COII) digunakan untuk penentuan DNA lembu; dan 2 primer untuk menentukan DNA babi iaitu DNA mitokondria tRNA-ATP8 dan Elemen nuklear berselang pendek (SINE).

\section{BAHAN DAN KAEDAH}

\section{PENYEDIAAN SAMPEL SURIMI}

Ikan kerisi (Nemipteridae) mentah diperoleh dari pasar basah Selayang Baru, Selangor bagi penghasilan sampel bebola ikan surimi berdasarkan kaedah Babji dan Gna (1994). Proses penghasilan surimi terdiri daripada penyiangan dan pencucian, pelunturan, pengekspresan dan penggilingan, diikuti proses pembungkusan dan pembekuan. Isi ikan diasingkan daripada tulangnya manakala dua kali basuhan garam $0.2 \%$ dan $0.3 \%$ (w/w) (Chemiz, MY) dilakukan bagi memisahkan isi daripada lemak ikan dan memperbaiki warna surimi. Isi ikan mentah yang telah diperah dengan kain kapas kasar kemudian ditambah dengan pelindung krio iaitu 3\% sukrosa (Sigma-Aldrich, USA), 3\% sorbitol (SigmaAldrich, USA) dan $0.3 \%(\mathrm{w} / \mathrm{w})$ natrium pirofosfat (Sigma-Aldrich, USA).

\section{PENYEDIAAN SAMPEL BEBOLA IKAN SURIMI}

Sebanyak 5\% (w/w) gelatin lembu (Sigma-Aldrich, USA) dan $5 \%(\mathrm{w} / \mathrm{w})$ gelatin babi (Sigma-Aldrich, USA) telah ditambahkan ke dalam surimi berdasarkan kaedah Kaewudom et al. (2012). Selepas adunan dibentuk menjadi bebola, rebusan dilakukan pada suhu $36{ }^{\circ} \mathrm{C}$ selama 30 min diikuti rebusan pada suhu 90 ${ }^{\circ} \mathrm{C}$ selama $10 \mathrm{~min}$. Akhir sekali, sampel bebola ikan surimi disejukkan di dalam air berais selama $30 \mathrm{~min}$ dan disimpan pada suhu $4{ }^{\circ} \mathrm{C}$ semalaman.

\section{KAEDAH RAWATAN TERMA}

Empat jenis rawatan terma telah dikenakan ke atas sampel bebola ikan surimi iaitu rebusan, pemanggangan, penggorengan dan autoklaf berdasarkan kajian Arslan et al. (2006) dengan modifikasi. Jadual 1 menunjukkan jenis rawatan terma yang terlibat berserta keterangan kaedah rawatan terma. 
JADUAL 1. Jenis rawatan terma ke atas sampel bebola ikan surimi

\begin{tabular}{ll}
\hline \multicolumn{1}{c}{ Jenis rawatan terma } & \multicolumn{1}{c}{ Keterangan kaedah rawatan terma } \\
\hline Rebusan & Bebola ikan surimi direbus di dalam air mendidih dengan $2 \%(\mathrm{w} / \mathrm{w})$ garam selama 2 min \\
Pemanggangan & $\begin{array}{l}\text { Bebola ikan surimi dimasak pada suhu } 180^{\circ} \mathrm{C} \text { di dalam ketuhar (Pensonic, MY) selama } 15 \\
\text { Penggorengan }\end{array}$ \\
Butoklaf & Bebola ikan surimi digoreng di atas kuali selama 5 min menggunakan minyak sayuran \\
& garam $2 \%(\mathrm{w} / \mathrm{w})$ dan diautoklaf pada suhu $12{ }^{\circ} \mathrm{C}, 15$ psi selama 20 min \\
\hline
\end{tabular}

\section{PENGEKSTRAKAN DNA}

Pengekstrakan DNA dilakukan terhadap $200 \mathrm{mg}$ sampel bebola ikan surimi menggunakan kit pengekstrakan makanan QIAGEN DNeasy ${ }^{\circledR} \operatorname{Mericon}^{\mathrm{TM}}(\mathrm{GY})$.

\section{PENCETUS OLIGONUKLEOTIDA KHUSUS-SPESIES}

Pencetus Bovine-F/Bovine-R yang mensasarkan 165 bp gen sitokrom oksidase II (COII) telah digunakan bagi pengesanan DNA lembu di dalam sampel bebola ikan surimi. Manakala pencetus tRNA-ATP8-F/tRNAATP8-R yang mensasarkan DNA mitokondria dan pencetus SINE-F/SINE-R yang mensasarkan DNA nukleus telah digunakan bagi pengesanan DNA babi. Kesemua pencetus diperoleh dari FirstBase Laboratories (MY). Jadual 2 menunjukkan senarai pencetus yang digunakan dalam kajian ini.

JADUAL 2. Senarai pencetus, jujukan, saiz amplikon dan gen sasaran

\begin{tabular}{|c|c|c|c|c|}
\hline Pencetus & Jujukan (5'-3') & $\begin{array}{c}\text { Saiz amplikon } \\
\text { (bp) }\end{array}$ & Gen sasaran & Rujukan \\
\hline Bovine-F & CAT CAT AGC AAT TGC CAT AGT CC & 165 & Sitokrom oksidase & Corona et al. (2007) \\
\hline \multirow{2}{*}{ Bovine- $\mathrm{R}$} & GTA CTA GTA GTA TTA GAG CTA & & II (COII) & \\
\hline & GAA TTA G & & & \\
\hline tRNA- ATP8-F & GCC TAA ATC TCC CCT CAA TGG TA & 212 & DNA mitokondria & Lahiff et al. (2001) \\
\hline \multirow{2}{*}{ tRNA- ATP8-R } & ATG AAA GAG GCA AAT AGA TTT & & tRNA- ATP8 & \\
\hline & TCG & & & \\
\hline SINE-F & GGA TCC GGC ATT GCC GTT AG & 161 & Elemen & Calvo et al. (2001) \\
\hline SINE-R & GTC TTT TTT TGC CAT TTC TTG G & & $\begin{array}{l}\text { berselang pendek } \\
\text { (SINE) }\end{array}$ & \\
\hline
\end{tabular}

\section{TINDAK BALAS BERANTAI POLIMERASE (PCR) SIMPLEKS}

Tindak balas berantai polimerase (PCR) simpleks bagi amplifikasi gen sasaran telah dijalankan di dalam sebatian tindak balas $25 \mu \mathrm{L}$ melibatkan $5 \mu \mathrm{L}$ templat DNA dan sejenis pencetus. Program kitar langkah adalah khusus mengikut jenis pencetus yang digunakan seperti di dalam Jadual 3. Bagi pencetus Bovine-F/Bovine-R, langkah dua hingga empat diulang sebanyak sepuluh kitaran manakala langkah lima hingga tujuh diulang sebanyak 20 kitaran. Bagi pencetus tRNA-ATP8-F/tRNAATP8-R dan SINE-F/SINE-R, langkah dua hingga empat diulang sebanyak 30 kitaran. 
JADUAL 3. Program kitar langkah bagi analisis PCR simpleks

\begin{tabular}{|c|c|c|c|}
\hline Pencetus & Langkah & Suhu $\left({ }^{\circ} \mathrm{C}\right) /$ Masa (minit) & Rujukan \\
\hline Bovine-F/ & Penyahaslian awal & $95 / 2$ & Corona et al. (2007) \\
\hline \multirow[t]{7}{*}{ Bovine- $\mathrm{R}$} & Penyahaslian & $94 / 1$ & \\
\hline & Penyepuhan & $58 / 1$ & \\
\hline & Pemanjangan & $72 / 1.5$ & \\
\hline & Penyahaslian & $90 / 1$ & \\
\hline & Penyepuhan & $58 / 1$ & \\
\hline & Pemanjangan & $72 / 1.5$ & \\
\hline & Pemanjangan akhir & $72 / 10$ & \\
\hline \multirow[t]{5}{*}{ tRNA-ATP8-F/ tRNA-ATP8-R } & Penyahaslian awal & $95 / 2$ & Lahiff et al. (2001) \\
\hline & Penyahaslian & $94 / 1$ & \\
\hline & Penyepuhan & $55 / 1$ & \\
\hline & Pemanjangan & $72 / 2$ & \\
\hline & Pemanjangan akhir & $72 / 10$ & \\
\hline SINE-F/ & Penyahaslian awal & $94 / 4$ & Calvo et al. (2001) \\
\hline \multirow[t]{4}{*}{ SINE-R } & Penyahaslian & $94 / 0.5$ & \\
\hline & Penyepuhan & $50 / 0.5$ & \\
\hline & Pemanjangan & $72 / 0.5$ & \\
\hline & Pemanjangan akhir & $72 / 5$ & \\
\hline
\end{tabular}

\section{TINDAK BALAS BERANTAI POLIMERASE (PCR) MULTIPLEKS}

Tindak balas berantai polimerase (PCR) multipleks bagi pengesanan DNA babi telah dijalankan di dalam sebatian tindak balas $25 \mu \mathrm{L}$ melibatkan $5 \mu \mathrm{L}$ templat DNA dan dua pencetus khusus babi tRNA-ATP8-F/tRNA-ATP8-R dan SINE-F/SINE-R secara serentak bagi setiap tindak balas. Proses pengoptimuman dilakukan berdasarkan penetapan empat program kitar langkah berbeza dengan perubahan ketara pada suhu penyepuhan yang digunakan $\left(52,53,54\right.$ dan $\left.55^{\circ} \mathrm{C}\right)$.

\section{ELEKTROFORESIS GEL AGAROSA}

Elektroforesis gel agarosa telah dilakukan ke atas larutan hasil tindak balas PCR menggunakan gel agarosa 2.5\% (w/v) pada $100 \mathrm{~V}$ selama $45 \mathrm{~min}$. Larutan penimbal Tris asid asetik EDTA (TAE) 1\%(w/v) digunakan sebagai medium larian manakala GeneRuler ${ }^{\mathrm{TM}} 168$ penanda DNA bersaiz 100 bp digunakan sebagai rujukan anggaran saiz amplikon. Gel agarose yang telah diprawarnakan dengan Maestrosafe ${ }^{\mathrm{TM}}$ Pre-Stained Nucleic Acid Stains (V-BioScience, MY) diperhatikan dan direkodkan menggunakan pengimbas gel Syngene GBOX $\mathrm{EF}^{2}$ (Syngene, UK).

\section{HASIL DAN PERBINCANGAN}

Sampel surimi dan bebola ikan surimi telah berjaya dihasilkan daripada ikan kerisi (Nemipteridae) mentah. Jumlah keseluruhan $10 \%(\mathrm{w} / \mathrm{v})$ gelatin yang dicampurkan semasa penyediaan sampel bebola ikan surimi adalah berdasarkan kaedah yang pernah dilakukan oleh Kaewudom et al. (2012) dalam penyediaan surimi daripada spesies ikan yang sama menggunakan gelatin ikan. Penambahan gelatin di dalam sampel bebola ikan surimi adalah sebagai protein penggelan dan menambah kandungan cecair di dalamnya (Sahilah et al. 2016).

Pengekstrakan DNA daripada kesemua sampel bebola ikan surimi dalam kajian ini telah mendapati jumlah DNA yang sangat sedikit. Ini disebabkan kepekatan DNA daripada gelatin yang telah dicampurkan ke dalam sampel bebola ikan surimi adalah rendah akibat pemprosesan berasid (babi) atau beralkali (lembu) yang digunakan dalam pengekstrakan gelatin (Nur Azira et al. 2012). Pemprosesan sampel seperti pemanasan dan tekanan tinggi merupakan faktor kritikal yang mempengaruhi kepekatan DNA kerana boleh menyebabkan degradasi DNA kepada fragmen yang lebih pendek dan kesukaran DNA dikesan (Teletchea et 
al. 2005). Tambahan pula, produk makanan merupakan matriks yang kompleks dengan kemungkinan kehadiran molekul lain lalu menghasilkan kepekatan DNA dengan berketulenan yang rendah. Isu yang sama juga pernah dilaporkan oleh Mafra et al. (2008) dan Martin et al. (2007) yang turut mengkaji pengekstrakan DNA daripada produk makanan dengan memberikan kepekatan yang rendah. Walau kepekatan DNA yang berjaya diekstrak dalam kajian ini adalah rendah, ia mencukupi untuk digunakan dalam analisis PCR. Ini ditunjukkan seperti keputusan yang terdapat pada Rajah 1 hingga 3.

Analisis PCR simpleks dalam kajian ini melibatkan pengesanan dua spesies gelatin yang berbeza iaitu gelatin lembu dan babi. Oleh itu, penggunaan primer khusus terhadap spesies haiwan tersebut bertujuan untuk menentukan kehadiran DNA lembu dan DNA babi di dalam sampel bebola ikan surimi diikuti pengoptimuman analisis PCR multipleks bagi menentukan kehadiran DNA babi. Bagi pengesanan gelatin lembu, Rajah 1 menunjukkan hasil amplifikasi PCR simpleks menggunakan primer lembu Bovine-F/Bovine-R yang mensasarkan DNA mitokondria daripada lima sampel bebola ikan surimi yang dikenakan perawatan terma (rebusan, panggang, goreng dan autoklaf). DNA gelatin lembu berjaya dikesan daripada semua sampel dengan penghasilan amplikon bersaiz 165 bp. Manakala, Rajah 2 dan 3 adalah hasil analisis PCR simpleks bagi pengesanan DNA babi yang masing-masing mensasarkan DNA mitokondria pada gene transfer RNA for lysine

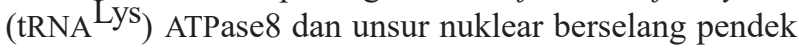
(SINE). Kedua-dua primer khusus babi tRNA-ATP8-F/ tRNA-ATP8-R dan SINE-F/SINE-R masing-masing didapati berjaya mengamplifikasi gen sasaran dengan penghasilan amplikon bersaiz 212 bp dan $161 \mathrm{bp}$.

Berdasarkan Rajah 1 hingga 3, kesemua rawatan terma rebusan, panggang, goreng dan autoklaf pada suhu dan masa yang telah ditetapkan dalam kajian ini didapati tidak memberi kesan kerosakan terhadap DNA, ini membolehkan gen sasaran untuk kesemua primer berjaya diamplifikasikan. Walau bagaimanapun, kaedah autoklaf menyebabkan jalur yang dihasilkan pada gel agarosa agak kabur berbanding dengan rawatan yang lain. Ini menunjukkan kesan rawatan terma autoklaf pada suhu $121{ }^{\circ} \mathrm{C}$, boleh menyebabkan kerosakan DNA berbanding lain-lain rawatan terma berdasarkan pemerhatian ke atas jalur amplikon selepas amplifikasi PCR. Oleh itu, faktor kehadiran tekanan pada 15 psi dan suhu $121{ }^{\circ} \mathrm{C}$ semasa rawatan terma ke atas sampel didapati memberi kesan ke atas pengesanan DNA lembu dan babi menggunakan analisis PCR berbanding faktor suhu rawatan dan tempoh masa rawatan terma. Keputusan kajian ini seiring dengan kajian yang dijalankan oleh Erwanto et al. (2009) yang menyatakan bahawa kesan pemprosesan oleh pelbagai rawatan terma tanpa tekanan tidak memberi kesan yang signifikan terhadap pengesanan serpihan DNA. Manakala, kajian oleh Matsunaga et al. (1999) terhadap daging kuda yang diautoklaf pada suhu $120{ }^{\circ} \mathrm{C}$ selama $30 \mathrm{~min}$ didapati tidak dapat mengamplikasi amplikon bersaiz 439 bp daripada DNA mitokondria (mtDNA). Namun, kajian oleh Arslan et al. (2006) berjaya mengesan DNA haiwan pada sampel yang diautoklaf selama $90 \mathrm{~min}$. Perbezaan ini mungkin disebabkan oleh saiz rantau amplifikasi yang besar digunakan oleh Matsunaga et al. (1999) berbanding yang digunakan oleh Arslan et al. (2006). Hasil positif pengesanan DNA lembu dan babi daripada gelatin yang terkandung dalam surimi yang diautoklaf dalam kajian ini adalah seiring dengan hasil kajian yang dijalankan oleh Arslan et al. (2006) yang menyatakan DNA pada sampel yang dikenakan rawatan autoklaf masih boleh dikesan dan hanya akan terjejas teruk pada suhu yang sangat tinggi dan masa yang lebih lama.

Selain itu, berdasarkan pemerhatian ke atas kesemua hasil analisis PCR simpleks, jenis gen sasaran sama ada berasal daripada DNA mitokondria atau DNA nukleus turut mempengaruhi hasil amplifikasi. Amplifikasi PCR terhadap DNA mitokondria menghasilkan jalur amplikon yang lebih jelas walaupun memiliki saiz gen sasaran yang lebih panjang (165 dan 212 bp) berbanding DNA nukleus (161 bp). Hal ini adalah disebabkan oleh kehadiran sejumlah mitokondria di dalam sel somatik dengan gandaan salinan DNA mitokondria di dalam satu mitokondria (Refinetti et al. 2017). Justeru, keadaan ini meningkatkan peluang dan potensi untuk mendapat keputusan yang positif walaupun sampel diproses dengan suhu yang tinggi (Verkaar et al. 2002).

Bagi mensasarkan lebih daripada satu jenis gen sasaran, terdapat empat penetapan keadaan pengoptimuman yang telah terlibat dalam analisis PCR multipleks bagi pengesanan DNA babi di dalam sampel produk bebola ikan surimi. Unsur kritikal yang dimanipulasi ialah suhu dan tempoh masa dalam program kitar langkah PCR melibatkan langkah penyahaslian awal, penyahaslian, penyepuhan, pemanjangan dan pemanjangan akhir. Pemilihan suhu dan tempoh masa dalam program kitar langkah PCR yang berbeza akan menghasilkan hasil amplifikasi yang berbeza. Berdasarkan kajian pengoptimuman keadaan PCR oleh Obradovic et al. (2013), parameter kritikal yang perlu diambil kira ialah suhu penyepuhan kerana perbezaan suhu sebanyak $1{ }^{\circ} \mathrm{C}$ sahaja boleh menghasilkan produk amplifikasi berbeza. Dalam kajian ini, pengoptimuman PCR multipleks telah berjaya dilakukan pada suhu penyahaslian awal pada $95{ }^{\circ} \mathrm{C}$ selama $2 \mathrm{~min}$, diikuti 30 kitaran penyahaslian pada $94{ }^{\circ} \mathrm{C}$ selama $1 \mathrm{~min}$, penyepuhan pada $55{ }^{\circ} \mathrm{C}$ selama $1 \mathrm{~min}$, pempolimeran pada $72{ }^{\circ} \mathrm{C}$ selama 2 min dan pemanjangan akhir pada $72{ }^{\circ} \mathrm{C}$ selama $10 \mathrm{~min}$, dengan penghasilan amplikon 212 dan 161 bp. Pengoptimuman yang menggunakan suhu penyepuhan pada suhu 51,53 dan $54{ }^{\circ} \mathrm{C}$ pula tidak menunjukkan sebarang hasil amplifikasi. Rajah 4 menunjukkan hasil amplifikasi PCR multipleks bagi surimi yang telah diberi rawatan terma yang berbeza yang mengandungi $5 \%(\mathrm{w} / \mathrm{w})$ gelatin lembu dan 5\% gelatin babi dengan menggunakan primer tRNA-ATP8 kajian Lahiff et al. (2001) dan primer SINE kajian Calvo et al. (2001) secara serentak.

Pengoptimum program bagi PCR multipleks 
bertujuan membolehkan keadaan yang optimum dicapai bagi kesemua primer yang digunakan dalam satu asai. Kehadiran lebih daripada sepasang primer dalam PCR multipleks meningkatkan penghasilan produk amplifikasi palsu, terutamanya disebabkan oleh pembentukan primer dimer hasil interaksi antara primer (Brownie et al. 1997; Tao et al. 2020). Produk bukan khusus ini boleh diamplifikasi dengan lebih cekap berbanding sasaran yang dikehendaki, menggunakan komponen tindak balas dan menjejaskan proses penyepuhan dan pemanjangan. Oleh itu, pengoptimuman PCR multipleks bertujuan untuk meminimumkan atau mengurangkan interaksi tersebut seperti satu analisis pengoptimuman PCR multipleks oleh Sultana et al. (2018) yang telah berjaya mengesan dan membezakan antara tiga komponen gelatin dengan ketepatan $100 \%$. Ujian empirik dan pendekatan cuba jaya telah digunakan dalam kebanyakan analisis PCR multipleks apabila menguji beberapa primer (Alía et al. 2019; Ji et al. 2019) kerana tiada cara yang lebih khusus untuk meramalkan ciri-ciri prestasi kombinasi primer yang dipilih (Henegariu et al. 1997).

\section{Kesimpulan}

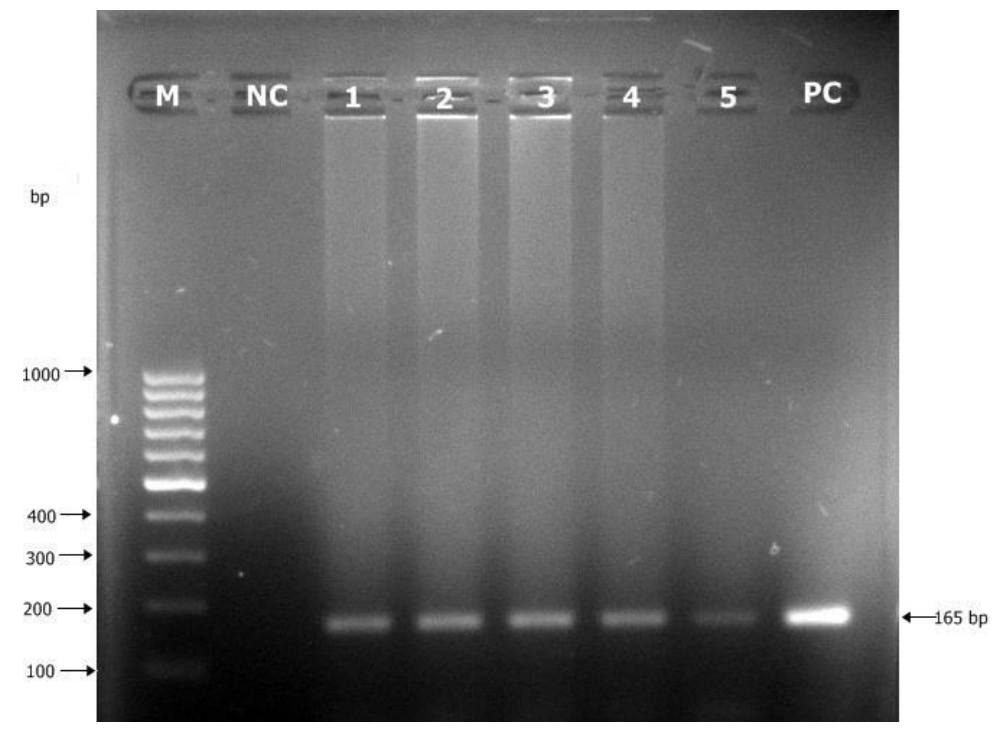

RAJAH 1. Hasil amplifikasi PCR bagi sampel surimi dengan 5\% (w/w) gelatin lembu dan $5 \%(\mathrm{w} / \mathrm{w})$ gelatin babi yang telah diberi rawatan terma dengan menggunakan primer BOVINE. Lajur M: Penanda DNA 100 bp; Lajur NC: Kawalan negatif; Lajur 1: Mentah; Lajur 2: Rebus; Lajur 3: Panggang; Lajur 4: Goreng; Lajur 5: Autoklaf; Lajur PC: Kawalan positif (165 bp)

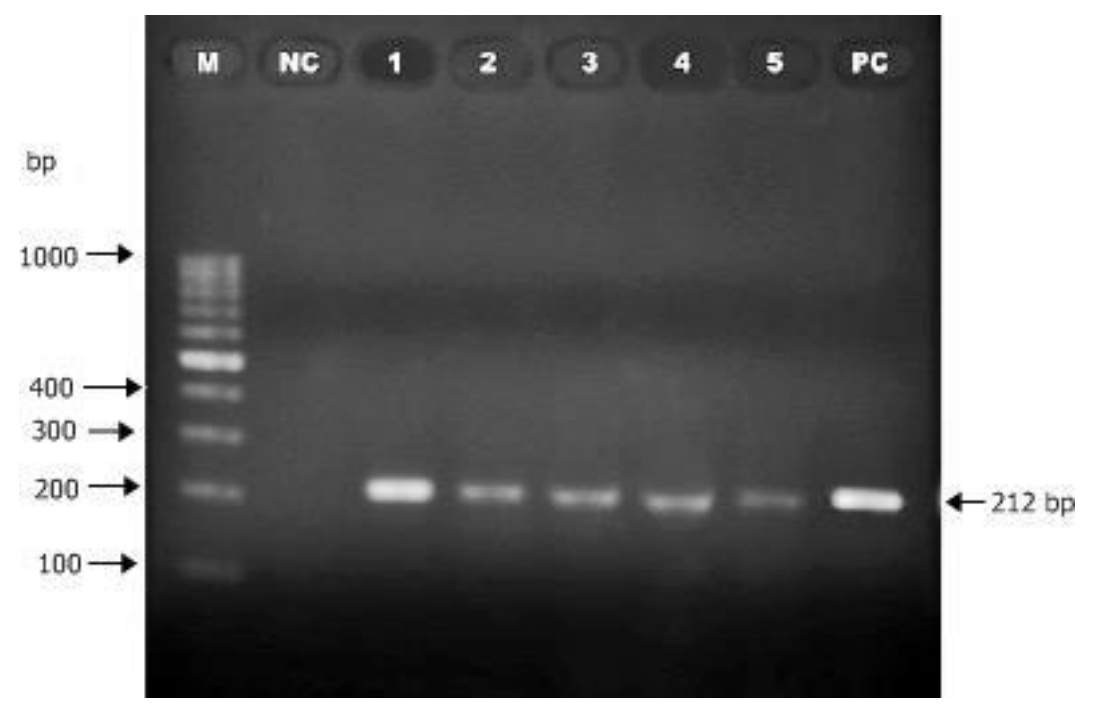

RAJAH 2. Hasil amplifikasi PCR simpleks bagi sampel surimi dengan 5\% (w/w) gelatin lembu dan $5 \%(\mathrm{w} / \mathrm{w})$ gelatin babi yang telah diberi rawatan terma dengan menggunakan primer tRNA-ATP8. Lajur M: Penanda DNA 100 bp; Lajur NC: Kawalan negatif; Lajur 1: Mentah; Lajur 2: Rebus; Lajur 3: Panggang; Lajur 4: Goreng; Lajur 5: Autoklaf; Lajur PC: Kawalan positif (212 bp) 


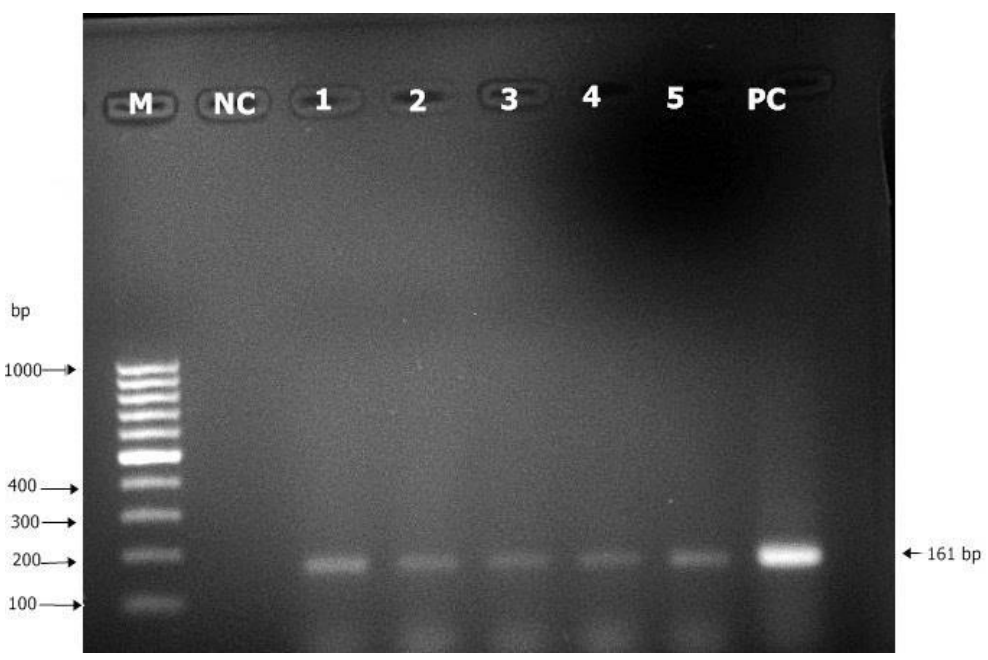

RAJAH 3. Hasil amplifikasi PCR bagi sampel surimi dengan 5\% (w/w) gelatin lembu dan $5 \%(\mathrm{w} / \mathrm{w})$ gelatin babi yang telah diberi rawatan terma dengan menggunakan primer SINE. Lajur M: Penanda DNA 100 bp; Lajur 1: Kawalan negatif; Lajur 2: Mentah; Lajur 2: Rebus; Lajur 3: Panggang; Lajur 4: Goreng; Lajur 5: Autoklaf; Lajur PC: Kawalan positif (161 bp)

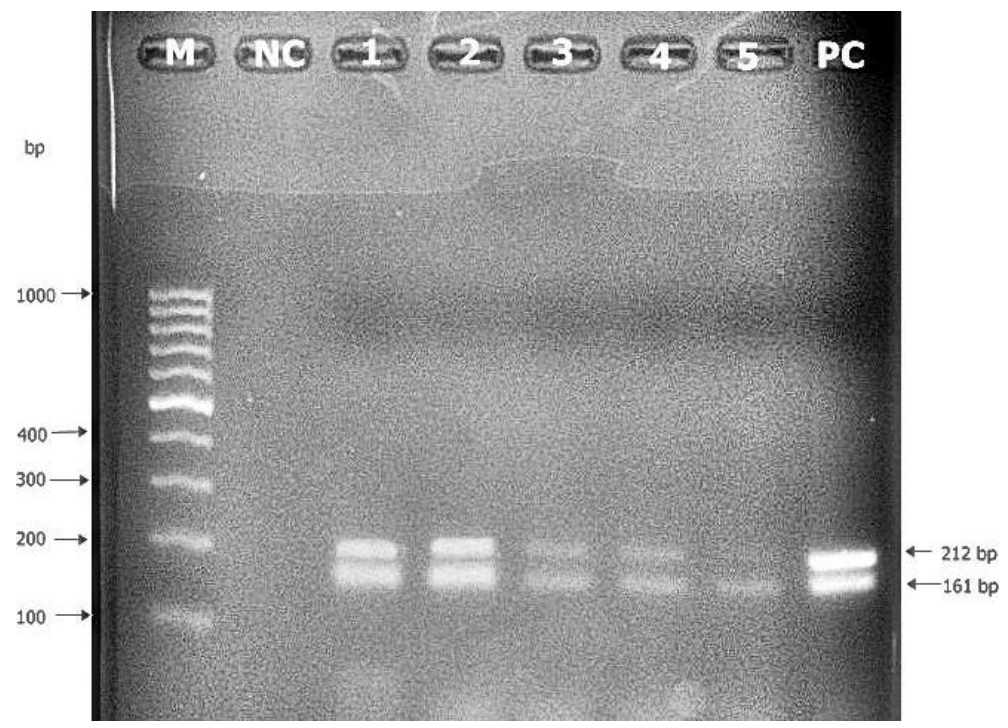

RAJAH 4. Hasil amplifikasi PCR multipleks bagi sampel surimi dengan 5\% (w/w) gelatin lembu dan 5\% (w/w) gelatin babi yang telah diberi rawatan terma dengan menggunakan primer tRNA-ATP8 dan SINE. Lajur M: Penanda DNA 100 bp; Lajur NC: Kawalan negatif; Lajur 1: Mentah; Lajur 2: Rebus; Lajur 3: Panggang; Lajur 4: Goreng; Lajur 5: Autoklaf; Lajur PC: Kawalan positif (212 dan $161 \mathrm{bp)}$

Amplifikasi DNA gelatin lembu dan babi menunjukkan hasil yang positif dengan menghasilkan amplikon pada 165 bp bagi pengesanan DNA lembu serta 212 bp dan $161 \mathrm{bp}$, masing-masing bagi pengesanan DNA babi walaupun pada sampel yang telah diberikan rawatan terma termasuk autoklaf $\left(121^{\circ} \mathrm{C}, 20 \mathrm{~min}\right)$. Pengoptimuman PCR multipleks menggunakan pencetus khusus babi tRNAATP8 dan SINE telah berjaya dilakukan pada program kitar langkah yang melibatkan langkah penyepuhan pada $55^{\circ} \mathrm{C}$. Pendekatan PCR ini boleh digunakan oleh penguatkuasa undang-undang dan penyelidik untuk pemantauan ketulenan dan kualiti daging dan produk daging dan terbitannya dalam pasaran bagi pengesahan halal. 


\section{PENGHARGAAN}

Kami ingin mengucapkan terima kasih kepada Fakulti Sains dan Teknologi (FST), Universiti Kebangsaan Malaysia (UKM), Bangi atas sokongan dan bekalan alatan penyelidikan. Kajian ini dibiaya menggunakan geran penyelidikan AP2017-002/1 dan MI-2019-021 dari Universiti Kebangsaan Malaysia.

\section{RUJUKAN}

Alía, A., Andrade, M.J., Córdoba, J.J., Martín, I. \& Rodríguez, A. 2020. Development of a multiplex real-time PCR to differentiate the four major Listeria monocytogenes serotypes in isolates from meat processing plants. Food Microbiology 87: 103367

Altun, B.E. \& Yildiz, Z. 2018. Surimi processing technology. Acta Biologica Turcica 31(4): 203-208.

Arslan, A., Ilhak, I.O. \& Calicioglu, M. 2006. Effect of method of cooking on identification of heat processed beef using polymerase chain reaction (PCR) technique. Meat Science 72(2): 326-330.

Babji, A.S. \& Gna, S.K. 1994. Changes in colour, pH, WHC, protein extraction and gel strength during processing of chicken surimi (ayami). ASEAN Food Journal 9: 54-59.

Brownie, J., Shawcross, S., Theaker, J., Whitcombe, D., Ferrie, R, Newton, C. \& Little, S. 1997. The elimination of primerdimer accumulation in PCR. Nucleic Acids Res. 25(16): 3235-3241.

Calvo, J.H., Zaragoza, P. \& Osta, R. 2001. Technical Note: A quick and more sensitive method to identify pork in processed and unprocessed food by PCR amplification of a new specific DNA fragment. Journal of Animal Science 79(8): 2108-2112.

Corona, B., Lleonard, R., Carpio, Y., Uffo, O. \& Martinez, S. 2007. PCR detection of DNA bovine, ovine-caprine and porcine origin in feed as part of a bovine spongiform encephalopathy control program. Spanish Journal of Agricultural Research 3: 312-317.

Dasar Agromakanan 2011-2020. 2011. Bahagian Perancangan Strategik dan Antarabangsa Kementerian Pertanian dan Industri Asas Tani. Percetakan Kuala Lumpur: Watan Sdn. Bhd: https://www.moa.gov.my/documents/20182/29029/ $\mathrm{DAN}+2011-2020+-8 \times 11$.pdf/bf4271f7-97e0-4db3-82fa$293 \mathrm{ce} 31 \mathrm{c} 4615$.

Erwanto, Y., Abidin, M.Z. \& Rohman, A. 2012. Pig species identification in meatballs using polymerase chain reactionrestriction fragment length polymorphism for halal authentication. International Food Research Journal 19(3): 901-906.

Ghovvati, S., Nassiri, M.R., Mirhoseini, S.Z., Moussavi, A.H. \& Javadmanesh, A. 2009. Fraud identification in industrial meat products by multiplex PCR assay. Food Control 20(8): 696-699.

Guo, B., Zhou, A., Liu, G., Ying, D., Xiao, J. \& Miao, J. 2019. Changes ofphysicochemical properties of greater lizardfish (Saurida tumbil) surimi gels treated with high pressure combined with microbial transglutaminase. Journal of Food Processing and Preservation 43(10): e14150.

Henegariu, O., Heerema, N.A., Dlouhy, S.R., Vance, G.H. \& Vogt, P.H. 1997. Multiplex PCR: Critical parameters and step-bystep protocol. Biotechniques 23(3): 504-511.
Jaswir, I., Yusof, N., Jamal, P. \& Jami, M.S. 2017. Novel method for gelatin extraction of various local fish using High Pressure Processing (HPP). International Food Research Journal 24(Suppl): S533-S539.

Ji, K., Xu, Y., Sun, J., Huang, M., Jia, X., Jiang, C. \& Feng, Y. 2020. Harnessing efficient multiplex PCR methods to detect the expanding $\operatorname{Tet}(\mathrm{X})$ family of tigecyclin resistance genes. Virulence 11(1): 49-56.

Kaewudom, P., Benjakul, S. \& Kijroongrojana, K. 2012. Effect of bovine and fish gelatin in combination with microbial transglutaminase on gel properties of threadfin bream surimi. International Aquatic Research 4(1): 12-24.

Kaewudom, P., Benjakul, S., Kijroongrojana, K. 2013. Properties of surimi gel as influenced by fish gelatin and microbial transglutaminase. Food Bioscience 1: 39-47.

Lahiff, S., Glennon, M., O’Brien, L., Lyng, J., Smith, T., Maher, M. \& Shilton, N. 2001. Species-specific PCR for the identification of ovine, porcine and chicken species in meat and bone meal (MBM). Molecular and Cellular Probes 15(1): 27-35.

Mafra, I., Ferreira, I.M. \& Oliveira, M.B.P. 2008. Food authentication by PCR-based methods. European Food Research and Technology 227(3): 649-665.

Mahmoodani, F., Ardekani, V.S., Fern, S.S., Salma, M.Y. \& Babji, A.S. 2014. Optimization of extraction and physicochemical properties of gelatin from pangasius catfish (Pangasius sutchi) skin. Sains Malaysiana 43(7): 995-1002.

Martin, I., Garcia, T., Fajardo, V., Lopez-Calleja, I., Hernandez, P.E., Gonzalez, I. \& Martin, R. 2007. Species-specific PCR for the identification of ruminant species in foodstuffs. Meat Science 75(1): 120-127.

Matsunaga, T., Chikuni, K., Tanabe, R., Muroya, S., Shibata, K., Yamada, J. \& Shinmura, Y. 1999. A quick and simple method for the identification of meat species and meat products by PCR assay. Meat Science 51(2): 143-148.

Nakyinsige, K., Man, Y.B.C. \& Sazili, A.Q. 2012. Halal authenticity issues in meat and meat products. Meat Science 91(3): 207-214.

Nikzad, J., Shahhosseini, S., Tabarzad, M., Nafissi-Varcheh, N. \& Torshabi, M. 2017. Simultaneous detection of bovine and porcine DNA in pharmaceutical gelatin capsules by duplex PCR assay for Halal authentication. DARU Journal of Pharmaceutical Sciences 25(3): 1-11.

Nur Azira, T., Amin, I. \& Che Man, Y.B. 2012. Differentiation of bovine and porcine gelatins in processed products via Sodium Dodecyl Sulphate Polyacrylamide Gel Electrophoresis (SDS-PAGE) and principal component analysis (PCA) techniques. International Food Research Journal 19(3): 1175-1180.

Obradovic, J., Jurisic, V., Tosic, N., Mrdjanovic, J., Perin, B., Pavlovic, S. \& Djordjevic, N. Optimization of PCR conditions for amplification of GC-Rich EGFR promoter sequence. Journal of Clinical Laboratory Analysis 27(6): 487-493.

Pascoal, A., Prado, M., Calo, P., Cepeda, A. \& Velasquez, J.B. 2005. Detection of bovine DNA in raw and heat-processed foodstuffs, commercial foods and specific risk materials by a novel specific polymerase chain reaction method. European Food Research and Technology 220(3-4): 444450.

Refinetti, P., Warren, D., Morgenthaler, S. \& Ekstrøm, P.O. 2017. Quantifying mitochondrial DNA copy number using robust 
regression to interpret real time $\mathrm{PCR}$ results. $B M C$ Research Notes 10(593): 1-7.

Repin, R.A.M., Shahimi, S., Lamri, M.F., Ghani, M.A. \& Mutalib, S.A. 2019. Characterization of Lysinibacillus spp. (Strain G6) for hydrolysing porcine gelatine. Malaysian Applied Biology Journal 48(2): 33-39.

Sahilah, A.M., Liyana, L., Aravindran, S., Aminah, A. \& Mohd Khan, A. 2016. Halal authentication in Malaysia context: Potential adulteration of non-Halal ingredients in meatballs and surimi products. International Food Research Journal 23(5): 1832-1838

Shabani, H., Mehdizadeh, M., Mousavi, S.M., Dezfouli, E.A., Solgi, T., Khodaverdi, M., Rabiei, M., Rastegar, H. \& Alebouyeh, M. 2015. Halal authenticity of gelatin using species-specific PCR. Food Chemistry 184: 203-206.

Shahimi, S., Abd Mutalib, S., Nazri, W.S.W., Abdullah, A. \& Sani, N.A. 2018. Comparison of DNA profiling between fishes and pork meat using polymerase chain reactionrestriction fragment length polymorphisms (PCR-RFLP) analysis. Sains Malaysiana 47(7): 1535-1540.

Shitole, S.S. \& Balange, A.K. 2014. Enhancement of gel strength of surimi from Japanese threadfin beam (Nemipterus japonicas Bloch, 1791) using seaweed extract. Fishery Technology 51: 102-105.

Sultana, S., Hossain, M.M., Zaidul, I.S.M. \& Ali, M.E. 2018. Multiplex PCR to discriminate bovine, porcine, and fish DNA in gelatin and confectionery products. LWT-Food Science and Technology 92: 169-176.
Tao, J., Liu, W., Ding, W., Han, R., Shen, Q., Xia, Y., Zhang, Y. \& Sun, W. 2020. A multiplex PCR assay with a common primer for the detection of eleven foodborne pathogens. Journal of Food Science 85(3): 744-754.

Teletchea, F., Maudet, C. \& Hanni, C. 2005. Food and forensic molecularidentification: Update and challenges. Trends in Biotechnology 23(7): 359-366.

Verkaar, E.L.C., Nijman, I.J., Boutaga, K. \& Lenstra, J.A. 2002. Differentiation of cattle species in beef by PCR-RFLP of mitochondrial and satellite DNA. Meat Science 60: 365369

Yoshida, T., Nomura, T., Shinoda, N., Kusama, T., Kadowaki, K. \& Sugiura, K. 2009. Development of PCR primers for the detection of porcine DNA in feed using mtATP6 as the target sequence. Journal of the Food Hygienic Society of Japan 50(2): 89-92.

Department of Food Science

Faculty of Science and Technology

Universiti Kebangsaan Malaysia

43600 UKM Bangi, Selangor Darul Ehsan

Malaysia

*Pengarang untuk surat-menyurat; email: sahilah@ukm.edu.my

Diserahkan: 31 Oktober 2019

Diterima: 8 April 2020 